\title{
Nomenclatural changes in the genus Bremeria (Rubiaceae)
}

\author{
A.P. Davis ${ }^{1}$, S.G. Razafimandimbison ${ }^{2}$, S. Andriambololonera ${ }^{3}$
}

Key words

\section{Bremeria}

Gaertnera

Madagascar

Mascarenes

Mussaenda

nomenclature

Rubiaceae

\begin{abstract}
Five new combinations are made in the genus Bremeria: B. arachnocarpa, $B$. eriantha, $B$. scabrella, $B$. landia var. holosericea, and B. landia var. stadmanii. Bremeria gerrardii is conspecific with Gaertnera phanerophlebia, and thus excluded from Bremeria. Lectotypes are designated for Mussaenda erectiloba var. scabrella, M. stadmanii, and M. trichophlebia.
\end{abstract}

Published on 21 January 2011

\section{INTRODUCTION}

On revealing the polyphyly of Mussaenda Burm. ex L., Alejandro et al. (2005) described the genus Bremeria Alejandro \& Razafim. to accommodate all of the Indian Ocean species formerly placed in Mussaenda, except the widespread M. arcuata L. Bremeria is indigenous to Madagascar (18 endemic spp.) and the Mascarenes (Mauritius and Reunion; one endemic $\mathrm{sp}$. ); its species are found in humid to subhumid evergreen forests (Alejandro et al. 2005, Govaerts et al. 2009). Alejandro et al. (2005) formally transferred 19 species of Mussaenda to Bremeria, but further investigation of type material and other herbarium specimens shows that five new combinations are required for the genus. In addition, it is necessary to exclude B. gerrardii (Homolle) Razafim. \& Alejandro as it is a synonym of Gaertnera phanerophlebia Baker, and to revise the synonymy of $B$. trichophlebia (Baker) Razafim. \& Alejandro.

\section{MATERIALS AND METHODS}

Herbarium material of Bremeria was consulted at the Muséum national d'Histoire naturelle, Paris $(P)$, and Royal Botanic Gardens, Kew (K) (abbreviations after Holmgren et al. 1990).

\section{NEW COMBINATIONS}

1. Bremeria arachnocarpa (Wernham) A.P.Davis \& Razafim., comb. nov.

Mussaenda arachnocarpa Wernham, J. Bot. 52 (1914) 69. — Type: Scott Elliot 2624 (holo K), Madagascar, Fort Dauphin, May [1888-90]

Mussaenda lantziana Homolle (1938) 4. - Bremeria lantziana (Homolle) Razafim. \& Alejandro in Alejandro et al. (2005) 555, syn. nov. - Syntypes: Lantz S.n. (P), Madagascar. Domaine orientale, Matatane, July 1881; Decary 10999 (P), Madagascar, Fort Dauphin, Ebahika, 16 Nov. 1932.

\footnotetext{
Royal Botanic Gardens, Kew, Richmond, Surrey, TW9 3AB, UK; corresponding author e-mail: a.davis@kew.org.

2 Bergius Foundation, Royal Swedish Academy of Sciences and Botany Department, Stockholm University, SE-10691, Stockholm, Sweden; e-mail: sylvain.razafimandimbison@bergianska.se.

${ }^{3}$ Missouri Botanical Garden, B.P. 3391, Antananarivo 101, Madagascar; e-mail: sylvie.andriambololonera@mobot-mg.org.
}

Note - Mussaenda arachnocarpa and B. lantziana are conspecific. Both taxa are from humid forest areas near Fort Dauphin (Tolagnaro) in Southeast Madagascar. Mussaenda arachnocarpa has priority and therefore a new combination is required.

2. Bremeria eriantha (A.Rich.) A.P.Davis \& Razafim., comb. nov.

Mussaenda eriantha A.Rich., Mém. Rubiac. (1830) 166. — Type: Chapelier s.n. (holo P; iso P), Madagascar.

Mussaenda ramosissima Wernham (1914) 69. - Bremeria ramosissima (Wernham) Razafim. \& Alejandro in Alejandro et al. (2005) 556. - Type: Humblot 392 (holo K; iso P), Madagascar, Oct. 1883 (received).

\section{Bremeria scabrella (Wernham) A.P.Davis \& Razafim.,} comb. \& stat. nov.

Basionym: Mussaenda erectiloba Wernham var. scabrella Wernham, J. Bot. 52 (1914) 68. - Type: Scott Elliot 2607 (lectotype K, designated here), Madagascar, Toliara, Fort Dauphin, May [1888-90].

Notes - Bremeria scabrella is not like $B$. erectiloba but instead has a greater morphological similarity to $B$. pervillei (Wernham) Razafim. \& Alejandro, which comes from the subhumid forests (Sambirano) of Northeast Madagascar. Bremeria scabrella can be set apart from $B$. pervillei on the basis of the stiff pubescence (short hairs) on the under surface of the leaves (vs soft pubescence and longer hairs), sparsely pubescent inflorescence branches (vs densely pubescent), generally rather robust inflorescence parts (vs slender), and distinct (raised and rather thick) tertiary veins (vs flat to slightly raised and thin). Specimens Schatz \& Nicoll 1231 (K, MO), Malcomber 2626 (K, $\mathrm{MO})$, Randriamampionona 686 (K, MO) from Parcelle 1 of the Réserve Naturelle Intégrale d'Andohahela (near Fort Dauphin, in the District of Tolagnaro (Toliara)), fall within the circumscription of $B$. scabrella.

Wernham (1914) cites two specimens (syntypes) for $M$. erectiloba var. scabrella, Scott Elliot 2607 and Cloisel 97. The herbaria for these specimens were given as 'Hbb. Mus. Brit., Kew', which upon consultation of the relevant herbaria has to be Scott Elliot 2607 (K) and Cloisel 97 (BM). We designate specimen Scott Elliot 2607 (K) as the lectotype of M. erectiloba var. scabrella. 
4. Bremeria landia (Poir.) Razafim. \& Alejandro var. holosericea (Sm.) A.P.Davis \& Razafim., comb. nov.

Mussaenda holosericea Sm. in Rees, Cyclop. 24 (1813) 6. - Mussaenda landia Poir. var. holosericea (Sm.) Verdc. (1983) 549. - Type: Commerson s.n. (holo LINN-SM 352/7; iso P-LA, P), Reunión (lle Bourbon), 1773.

Note - When transferring Musseaenda landia to Bremeria, Alejandro et al. (2005) did not make a combination for var. holosericea. This distinct variety requires a valid name and so a new combination is made here.

5. Bremeria landia (Poir.) Razafim. \& Alejandro var. stadmanii (Michx. ex DC.) A.P.Davis \& Razafim., comb. nov.

Mussaenda stadmanii Michx. ex DC., Prodr. 4 (1830) 372 ('stadmanni'). Mussaenda landia Poir. var. stadmanii (Michx. ex DC.) Verdc. (1983) 549. - Lectotype: Sieber, Fl. Maurit. II 79 (lectotype G; isolectotypes E, K, P, designated here), Mauritius.

Note - When transferring Mussaenda landia to Bremeria, Alejandro et al. (2005) did not make a combination for var. stadmanii. This distinct variety requires a valid name and so a new combination is made here.

\section{LECTOTYPIFICATION OF MUSSAENDA TRICHOPHLEBIA AND SYNONYMY FOR BREMERIA TRICHOPHLEBIA}

\section{Bremeria trichophlebia (Baker) Razafim. \& Alejandro}

Bremeria trichophlebia (Baker) Razafim. \& Alejandro in Alejandro et al. (2005) 556. - Mussaenda trichophlebia Baker (1883) 166. - Type: Baron 1764 (lectotype K; isolectotype P, designated here), Central Madagascar. K sheet, Oct. 1882 (com. [sic]); P sheet, June 1889 (purchased).

Mussaenda macropoda Baker (1885) 410. - Type: Baron 2088 (holo K), Central Madagascar, Dec. 1883 (received).

Mussaenda asperula Wernham (1914) 67. - Bremeria asperula (Wernham) Razafim. \& Alejandro in Alejandro et al. (2005) 555, syn. nov. — Type: Baron 493 (holo BM; iso K, P), Central Madagascar, Oct. 1881 (received).

Notes - Alejandro et al. (2005) cite the syntypes of $M$. trichophlebia as 'Baron 493 (syntypes, K, P) [sic]', which is incorrect. Baker (1883) cites two syntypes in his protologue for M. trichophlebia: Baron 493 and Baron 1764. The specimen Baron 493 (BM) was selected by Wernham (1914: 67 — 'Baron 493 ! Hb. Mus. Brit.' ) as the holotype of $M$. asperula, with isotypes at $\mathrm{K}$ and $\mathrm{P}$. We hereby designate Baron $1764(\mathrm{~K})$ as the lectotype of M. trichophlebia.

We agree with Wernham (1914: 66) that M. macropoda is a synonym of $M$. trichophlebia and hereby reiterate his synonymy in order to avoid superfluous combinations in Bremeria.

\section{BREMERIA GERRARDII EXCLUDED FROM BREMERIA}

\section{Gaertnera phanerophlebia Baker}

Gaertnera phanerophlebia Baker (1885) 425. - Type: Baron 2982 (syntype $\mathrm{K}$, isosyntypes BM, P [June 1889 (purchased)]), Madagascar, Dec. 1883 (received); Baron 2372 (syntype K; isosyntype P), Central Madagascar, Dec. 1883 (received).

Mussaenda gerrardi [sic] Homolle (1938) 4. - Bremeria gerrardii (Homolle) Razafim. \& Alejandro in Alejandro et al. (2005) 555, syn. nov. - Type: Gerrard 37 (holo K), Madagascar.

Notes - Examination of type material shows that B. gerrardii represents Gaertnera phanerophlebia, an observation confirmed by recent study of Gaertnera (Malcomber \& Taylor 2009). Bremeria and Gaertnera are not closely related, the former belonging to tribe Mussaendeae (Alejandro et al. 2005), and the latter to tribe Gaertnereae (Bremer \& Manen 2000, Robbrecht \& Manen 2006, Razafimandimbison et al. 2008). Another one of the six Mussaenda species described by Homolle (1938) should also not be transferred to Bremeria, viz. M. crinita, which has since been shown to belong to Bertiera (Wittle \& Davis 2010). Bertiera is not closely related to tribe Mussaendeae, but instead belongs to tribe Bertiereae (Bridson \& Verdcourt 2003, Davis et al. 2007).

Acknowledgements We would like to thank the Muséum national d'Histoire naturelle, Paris $(\mathrm{P})$, the Royal Botanic Gardens, Kew $(\mathrm{K})$, and the Natural History Museum, London (BM), for allowing us to examine their material of Bremeria and Gaertnera. Rafaël Govaerts is gratefully acknowledged for his assistance with nomenclatural aspects of this contribution.

\section{REFERENCES}

Alejandro GD, Razafimandimbison SG, Liede-Schumann S. 2005. Polyphyly of Mussaenda inferred from ITS and TrnT-F data and its implication for generic limits in Mussaendeae (Rubiaceae). American Journal of Botany 92: $544-557$.

Baker JG. 1883. Contributions to the Flora of Madagascar. - Part II. Monopetalae. Journal of the Linnean Society, Botany 20: 159-236.

Baker JG. 1885. Further contributions to the Flora of Madagascar. - Second and final part. Journal of the Linnean Society, Botany 21: 407-455.

Bremer B, Manen JF. 2000. Phylogeny and classification of the subfamily Rubioideae (Rubiaceae). Plant Systematics and Evolution 225: 43-72.

Bridson DM, Verdcourt B. 2003. Rubiaceae. In: Pope GV (ed), Flora Zambesiaca, vol. 5, part 3: 379-720. Royal Botanic Gardens, Kew.

De Candolle AP. 1830. Prodromus systematis naturalis regni vegetabilis, vol. 4: 372. Treuttel \& Würtz, Paris

Davis AP, Chester M, Maurin O, Fay MF. 2007. Searching for the relatives of Coffea (Rubiaceae, Ixoroideae): the circumscription and phylogeny of Coffeeae based on plastid sequence data and morphology. American Journal of Botany 94: 313-329.

Govaerts R, Ruhsam M, Andersson L, Robbrecht E, Bridson DM, Davis AP, Schanzer I, Sonké B. 2009. World checklist of Rubiaceae. The Board of Trustees of the Royal Botanic Gardens, Kew. <http://apps.kew.org/wcsp/ rubiaceae>; accessed 13 October 2009.

Holmgren PK, Holmgren NH, Barnett LC. 1990. Index Herbariorum. ed. 8. Regnum Vegetabile 120.

Homolle A-M. 1938. Mussaenda nouveaux de Madagascar. Notulae Systematicae. Herbier du Museum de Paris 7: 1-7.

Malcomber ST, Taylor CM. 2009. A systematic revision of Gaertnera (Rubiaceae, Gaertnerae). Annals of Missouri Botanical Garden 94: 575-671.

Razafimandimbison SG, Rydin C, Bremer B. 2008. Evolution and trends in the Psychotrieae alliance (Rubiaceae) - A rarely reported evolutionary change of many-seeded carpels from one-seeded carpels. Molecular Phylogenetics and Evolution 48: 207-223.

Rees A. 1813. The Cyclopaedia, vol. 24. Longman etc., London.

Richard A. 1830. Mémoire sur le famille des Rubiacées: 166. Tastu, Paris. Robbrecht E, Manen J-F. 2006. The major evolutionary lineages of the coffee family (Rubiaceae, Angiosperms). Combined analysis (nDNA and cpDNA) to infer the position of Coptosapelta and Luculia, and supertree construction based on rbcL, rps16, trnL-trnF and atpB-rbcL data. A new classification in two subfamilies, Cinchonoideae and Rubioideae. Systematics and Geography of Plants 76: 85-146.

Verdcourt B. 1983. Notes on Mascarene Rubiaceae. Kew Bulletin 37: 521 574.

Wernham HF. 1914. The mussaendas of Madagascar. Journal of Botany 52: 64-72.

Wittle P, Davis AP. 2010. A revision of Madagascan Bertiera. Blumea 55: 105-110. 